\title{
Effect of Napier Grass on Economic Turkey Production in Bangladesh
}

Mohammad Asaduzzaman*

Department of Genetics and Animal Breeding, Faculty of Veterinary and Animal Science, Hajee Mohammad Danesh Science and Technology University, Dinajpur, Bangladesh, Bangladesh; moha.asad@gmail.com

\begin{abstract}
Objective: To test the hypothesis that a certain percent of Napier grass could be used as a replacement of concentrate for economic production of turkey. Method/Analysis: The feeding trial was a Completely Randomized Design (CRD) consisting of one control and two concentrate feed replacement treatments. Three treatments were: $\mathrm{T}_{1}=100 \%$ concentrate (control), $\mathrm{T}_{2}=75 \%$ concentrate $+25 \%$ grass and $\mathrm{T}_{3}=50 \%$ concentrate $+50 \%$ grass. Requirement of concentrate and Napier grass were determined and supplied on the basis of Dry Matter (DM). Turkeys of all treatments were fed with the feed of same composition. Findings: Significant $(\mathrm{P}<0.05)$ difference was observed in daily and weekly concentrate intake among the treatment groups. Napier grass intake also differed significantly $(\mathrm{P}<0.05)$. Similar final body weight was found in $\mathrm{T}_{1}(2006 \pm 102.5 \mathrm{~g})$ and $\mathrm{T}_{2}(2008 \pm 77.5 \mathrm{~g})$. Feed conversion efficiency was better $(\mathrm{P}<0.05)$ for $\mathrm{T}_{2}(2.54 \pm .01)$ and $\mathrm{T}_{3}$ $(2.63 \pm 0.05)$ than $\mathrm{T}_{1}(3.50 \pm 0.05)$. Survivability rate was higher $(\mathrm{P}<0.05)$ in $\mathrm{T}_{2}(100 \%)$ and $\mathrm{T}_{3}(100 \%)$ than $\mathrm{T}_{1}(93 \%)$. Production cost and profitability per turkey differed significantly $(\mathrm{P}<0.05)$. Although total revenue was similar in $\mathrm{T}_{1}$ and $\mathrm{T}_{2}$; net farm income, production index, rate of return on investment and capital turnover were significantly $(\mathrm{P}<0.05)$ higher in $\mathrm{T}_{2}$. Novelty: Finally, it was concluded that on the basis of DM, replacement of $25 \%$ concentrate by Napier grass resulted in not only equal weight gain as like $100 \%$ concentrate but also reduced cost of production without causing any detrimental effects on turkey aged between 5 to 14 weeks. Therefore, farmers of Bangladesh could use this feeding system for economic turkey production.
\end{abstract}

Keywords: Concentrate, Feed Efficiency, Growth, Napier Grass, Turkey+

\section{Introduction}

Farmers of developed countries of Europe and America have been rearing turkey (Meleagris gallopavo) for meat since many years but it is gradually becoming popular in Bangladesh recently.

It has habit of eating grass in pasture. Its meat is an excellent source of protein and has a good price-quality ratio ${ }^{\prime}$. Hence, it is very important to know the factors influence the productive performance and yield of turkey ${ }^{2}$. Napier grass (Pennisetum purpureum) is a popular grass, cultivated particularly by farmers of Bangladesh for dairy cattle feeding. It contains comparatively higher crude protein than other forage but as it becomes mature
Dry Matter (DM) increases and Crude Protein (CP) decreases ${ }^{3}$. So young stage of Napier grass could be an alternative for concentrate replacement for turkey.

Pressure is increasing on limited cultivable land of Bangladesh to produce rice for human consumption in the one hand and feeds in terms of concentrate and fodder production for feeding livestock, on the other hand. Because of increasing price of poultry feeds poultry industry of Bangladesh is searching alternatives without decreasing production performance of birds. Reducing the amount of concentrate by supplementing or replacing grass could be an effective alternative. In fact, farmers put most importance to feed efficiency because feed represents two-thirds of the total costs in poultry production. 
Importance of feed efficiency is high due to high cost of feed, which represents about $70 \%$ of the total cost of a turkey production system ${ }^{4}$. It is estimated that production and consumption of poultry meat in developing countries will increase by 3.6 percent per annum from 2005 to 2030 because of rising incomes, diversification of diets and expanding markets $s^{5}$. So it is important to the researchers of Bangladesh along with other developing countries to identify such a feeding system combining concentrate and fodder which could convert these feed components into meat more efficiently without compromising growth and profit.

Turkey is a good forager and according to the farmers of the Philippines feeding cost of turkey could be reduced almost $50 \%$ if green vegetables and grasses are used as supplement to commercial feeds ${ }^{6}$. By nature, poultry are omnivores and for this reason either supplying of quality grass or providing foraging opportunity could reduce the cost of production. It ${ }^{\underline{Z}}$ was reported that poultry could eat $5-20 \%$ of their diet from pasture and alfalfa which is essential to supply unidentified nutrients ${ }^{8}$.

Fiber has been regarded as nutrient diluents in poultry ${ }^{9}$ and a certain amount of dietary fiber is necessary for proper development and physiological function of gastrointestinal tract. Several researchers found positive influence on growth performance of geese by feeding bulky feeds ${ }^{10}$. Diet substitution is a commonly accepted principle of poultry nutrition to meet protein and energy requirements in relation to different growth period ${ }^{11}$. Studies showed that inclusion of moderate amount of different fiber in diet improved organ development as the gizzard ${ }^{12}-14$, increased HCL, bile acids and enzyme secretions ${ }^{15}, \underline{16}$. Digestible fiber after broken down by the bacteria in the digestive tract of bird becomes an excellent food source for beneficial bacteria like Lactobacillus sp. and Bifidobacteria ${ }^{17}$. Feeding of fiber produce lactic acid and lower $\mathrm{pH}$ due to fermentation of fiber creates a difficult environment for Salmonella and other pathogenic populations ${ }^{18}$. On the contrary, there is controversy about the efficiency with poultry regarding use of feed rich in fiber ${ }^{19}$.

Considering the above facts, it is necessary to find out a practical feeding system for economic turkey production. But there is little data available regarding use of Napier grass as a replacement of concentrate for turkey production in Bangladesh. Therefore, this study was carried out to test the hypothesis that a certain percent of Napier grass could be used as a replacement of concentrate for economic production of turkey.

\section{Materials and Methods}

\subsection{Study Site and Duration of Experiment}

The study was conducted at the Advanced Animal Research Farm of Faculty of Veterinary and Animal Science, Hajee Mohammad Danesh Science and Technology University (HSTU), Dinajpur, Bangladesh. All experimental conditions and animal procedures were approved by the Animal Care and Ethics Committee of HSTU. The experiment lasted for 12 weeks (5 to 14 weeks age of turkey) during the months May to July 2016.

\subsection{Experimental Design}

The feeding trial was a Completely Randomized Design (CRD) consisting of one control and two concentrate replacement treatments. A total of 90 , 4-week old poults were procured from a local turkey breeding farm. Poults were randomly allocated to three dietary treatment groups. Each group was made up of 3 replicates. The turkeys were reared in deep litter pens which were demarcated according to the diet groups. Both concentrate and fresh Napier grass were supplied to the treatment groups on the basis of Dry Matter (DM) and consumption pattern of turkeys. The amount of fresh grass for concentrate replacement was determined on the basis of DM intake of control group. DM content was kept equal for all groups. The feeding system of the three treatments was: Treatment $1\left(\mathrm{~T}_{1}\right)=100 \%$ concentrate (control), Treatment $2\left(\mathrm{~T}_{2}\right)=75 \%$ concentrate $+25 \%$ grass (on DM basis) and Treatment $3\left(\mathrm{~T}_{3}\right)=50 \%$ concentrate $+50 \%$ grass (on DM basis).

\subsection{Turkey Management}

Before arrival of poults the house was cleaned thoroughly with water and disinfectant. A foot bath was made in front of door of the house and it was dipped with potassium permanganate to maintain bio-security. All the turkeys involved in the experiment were treated equally in all respects, except supplying amount of concentrate and Napier grass. Turkeys of all treatments were fed with same diet. Commercial broiler grower concentrate feed 
manufactured by Farms Limited, Bangladesh, was fed to the turkeys of all treatments.

The experimental concentrate feed was prepared by using maize, rice polish, soybean meal, full fat soybean, animal protein, vitamin-mineral premix, amino acid, salt, toxin binder and antioxidant. The composition of the concentrate feed is presented in Table 1.

Napier grass was cultivated at the fodder field nearby to the turkey shed. It is also known as "Elephant grass", "Sudan grass" or "King grass". It was supplied to the turkeys by hanging procedure. This grass was harvested at the early stages of growth (5-7 weeks) when the nutrients such as carbohydrate, crude protein etc. were at higher level. Composition of Napier grass as analyzed by ${ }^{20}$ is given in Table 2 and it was also reported that young and immature Napier grass cut at $50 \mathrm{~cm}$ height were highly digestible.

Concentrate and water were supplied in plastic feeders and drinkers. Ad libitum water was made available all day long throughout the experimental period by using hanging drinkers. Before starting the experiment, a week was provided to the experimental turkeys as an adjustment period to be comfortable with their respective experimental diet. To avoid wastage and reduce the quantities of leftovers, supply of concentrate and grass was adjusted every week on the basis of consumption pattern. Concentrate and grass were supplied two times in a day: in the morning between at $8: 30$ to $9: 00$ a.m. and in the afternoon between at $3: 30$ to $4: 00$ p.m. To ensure freshness, grass was supplied directly from the field. Rice husk and wood shavings were used as litter. Each turkey was marked with colored plastic beads for proper identification. The environmental conditions of the experimental unit such as ventilation and illumination were supplied both naturally and mechanically. The environmental temperature was between $28-35^{\circ} \mathrm{C}$ and lighting schedule was $13 \mathrm{~h}$ light and $11 \mathrm{~h}$ dark in the experimental unit.

Table 1. Nutrient composition of the experimental concentrate for feeding turkey

\begin{tabular}{|l|c|}
\hline \multicolumn{1}{|c|}{ Nutrient } & Values \\
\hline Metabolizable Energy (Kcal/kg) & 3000 \\
\hline Crude protein (\%) & 19.3 \\
\hline Crude Fat (\%) & 5.0 \\
\hline Calcium (\%) & 0.90 \\
\hline Available Phosphorus (\%) & 0.42 \\
\hline
\end{tabular}

Source: Aftab Bahumukhi Farms Limited, Bangladesh.
Table 2. Chemical composition of Napier grass (Pennisetum purpureum) at $50 \mathrm{~cm}$ height

\begin{tabular}{|l|c|}
\hline Nutrient & \% \\
\hline Dry Matter (DM) & 37 \\
\hline Ash & 6 \\
\hline Crude Protein (CP) & 13.29 \\
\hline Dry Matter Digestibility (DMD) & 64 \\
\hline Neutral Detergent Fiber (NDF) & 51.37 \\
\hline Acid Detergent Lignin (ADL) & 3.5 \\
\hline Acid Detergent Fiber (ADF) & 37 \\
\hline Macro element & \\
\hline $\mathrm{P}$ & 0.07 \\
\hline $\mathrm{Ca}$ & 0.11 \\
\hline $\mathrm{Mg}$ & 0.05 \\
\hline $\mathrm{Na}$ & 0.17 \\
\hline $\mathrm{Minor}$ elements (ppm) & \\
\hline $\mathrm{Fe}$ & 193.6 \\
\hline $\mathrm{Mn}$ & 39 \\
\hline $\mathrm{Zn}$ & 50 \\
\hline $\mathrm{Cu}$ & 6.6 \\
\hline
\end{tabular}

Source: $\operatorname{In}^{20}$.

\subsection{Data Collection}

\subsubsection{Calculation of Productive Performance}

Concentrate and Napier grass were supplied after weighing by using a digital balance daily. Left over concentrate and grass were also weighed daily. The litter was sieved to determine the concentrate in wastage. All turkeys were weighed to obtain the initial weight and subsequently weighed weekly to obtain the weekly body weight and body weight gain. Other parameters measured during this period include concentrate intake, Feed Conversion Efficiency (FCE) and survivability rate. Growth and feed efficiency were measured using fo.llowing equations:

Growthrate $=\frac{\text { Total weight gainincertain time }}{\text { Total days of the experiment }}$

Feed coversion efficiency $(F C E)=\frac{\text { Concentrate feed intake }}{\text { Bodyweight gain }}$ 


\subsubsection{Calculation of Economic Performance}

Economic performance calculation was done using market prices of feed ingredients and other necessary items to compare the costs of different treatments. Price of turkey, feed, grass, electricity, labor, medication etc. were taken into account on the basis of market price during the experimental period in Bangladesh. The financial values of the study were calculated on the basis of the national money unit of Bangladesh. Average exchange rate of Bangladesh Bank over the research period was $1 \mathrm{USD}=80 \mathrm{BDT}$.

\subsubsection{Total Variable Cost (TVC)}

TVC is the cost of variable inputs such as feeds, labor and drugs used for production and it changes directly with the level of production.

\subsubsection{Total Fixed Cost (TFC)}

TFC is the cost of permanent items that does not vary when output changes and therefore has no influence on production decisions in short run.

\subsubsection{Total Revenue (TR)}

TR is the total money value of all output produced whether sold, consumed or in stock.

\subsubsection{Net Farm Income (NFI)}

NFI means difference between total returns and total expenses for production. It was calculated using the following equation:

$\mathrm{NFI}=\mathrm{TR}-(\mathrm{TVC}+\mathrm{TFC})$.

Where; NFI $=$ Net Farm Income $(\mathrm{NFI}), \mathrm{TR}=$ Total Revenue, TVC $=$ Total Variable Cost and TFC $=$ Total Fixed Cost.

\subsubsection{Profitability Index (PI)}

Profitability Index (PI) means the Net Farm Income (NFI) per unit of Total Revenue (TR) and it was calculated using following equation:

$$
P I=\frac{N F I}{T R}
$$

Where; PI $=$ Profitability Index, NFI $=$ Net Farm Income and $\mathrm{TR}=$ Total Revenue

\subsubsection{Rate of Return on Investment (RRI)}

RRI is the performance measure used to evaluate the efficiency of an investment or to compare the efficiency of different investments. It is calculated dividing the net farm income divided by total cost of investment and usually expressed as a percentage or ratio. RRI was calculated using following equation:

$$
R R I=\frac{N F I}{T C}
$$

Where; RRI = Rate of return on investment, $\mathrm{NFI}=$ Net farm income and $\mathrm{TC}=$ Total cost.

\subsubsection{Capital Turnover (CTO)}

It is the ratio of total revenue to total cost. It measures the efficiency of a business and provides information on the capability of business to deliver return per unit of money invested. It tells the farmers whether the business is viable and capable of offsetting its own cost. CTO was measured using following equation:

$$
C T O=\frac{T R}{T C}
$$

Where, $\mathrm{CTO}=$ Capital turnover, $\mathrm{TR}=$ Total revenue and $\mathrm{TC}=$ Total cost

\subsubsection{Depreciation}

To calculate the worth of each fixed cost items, the straight line method of depreciation was used. It was measured using equation mentioned below:

$$
\text { Depreciation cost }=\frac{\text { Purchase price }}{\text { Number of useful years of the asset }}
$$

\subsection{Statistical Analysis}

Effect of treatment on body weight, feed intake, feed efficiency, survivability and profitability were analyzed using the One-way ANOVA procedure in accordance with a Completely Randomized Design (CRD) following the GLM procedure of SPSS computer software $22.00^{21}$. Significance of differences among the means of treatments was compared by using Duncan's Multiple Range Test of the same package. All data were expressed as Mean \pm Standard Error of Mean (SEM). Differences were 
considered significant at the level of $\mathrm{P}<0.05$. The following linear model summarizes the statistics employed to analyze the data:

$$
\mathrm{Y}_{\mathrm{i}}=\mu+\mathrm{TR}_{\mathrm{i}}+\mathrm{E}_{\mathrm{i}}
$$

Where; $\mathrm{Y}_{\mathrm{i}}$ is the dependent variable, $\mu$ is the overall mean, $\mathrm{TR}_{\mathrm{i}}$ is the treatment effect and $\mathrm{E}_{\mathrm{i}}$ is the error.

\section{Results and Discussion}

\subsection{Feed Intake and Growth}

Results on concentrate and Napier grass intake, feed conversion efficiency, growth and survivability are presented in Table 3.

Both daily and weekly average concentrate intake differed significantly $(\mathrm{P}<0.05)$ among the treatment groups and highest concentrate intake occurred in $\mathrm{T}_{1}$. Concentrate intake in different weeks showed steady upward trend for all treatment groups except for $T_{1}$ at $11^{\text {th }}$ and $12^{\text {th }}$ weeks when intake was lower (Figure 1). Average daily and weekly grass intake differed significantly $(\mathrm{P}<0.05)$ between $\mathrm{T}_{2}$ and $\mathrm{T}_{3}$ groups (Figure 2). Although initial body weight was similar for all treatment groups, final body weight differed significantly $(\mathrm{P}<0.05)$. Statistically similar final body weight was found for $T_{1}$ and $\mathrm{T}_{2}$. Both daily and weekly body weight gain of $\mathrm{T}_{3}$ were significantly $(\mathrm{P}<0.05)$ lower from $\mathrm{T}_{1}$ and $\mathrm{T}_{2}$. Body weight at different weeks was similar for $\mathrm{T}_{1}$ and $\mathrm{T}_{2}$ all along the

$$
\text { Table 3. Feed intake and growth performance of turkey fe }
$$

\begin{tabular}{|c|c|c|c|c|}
\hline \multirow{2}{*}{ Variables } & \multicolumn{3}{|c|}{ Dietary Treatment Groups } & \multirow{2}{*}{$\begin{array}{c}\text { Level of } \\
\text { significance }\end{array}$} \\
\hline & $\mathrm{T}_{1}$ & $\mathbf{T}_{2}$ & $\mathbf{T}_{3}$ & \\
\hline Initial body weight (g) & $406.22 \pm 40.57$ & $407.00 \pm 30.05$ & $406.14 \pm 20.57$ & NS \\
\hline Av. weekly body weight gain (g) & $151.10 \pm 16.01^{\mathrm{a}}$ & $157.05 \pm 7.63^{\mathrm{a}}$ & $101.00 \pm 9.87^{\mathrm{b}}$ & * \\
\hline Av. daily body weight gain (g) & $21.31 \pm 2.33^{\mathrm{a}}$ & $22.33 \pm 1.20^{\mathrm{a}}$ & $14.33 \pm 1.45^{\mathrm{b}}$ & * \\
\hline Final body weight (g) & $2006 \pm 102.5^{\mathrm{a}}$ & $2008 \pm 77.5^{\mathrm{a}}$ & $1190 \pm 113.4^{c}$ & * \\
\hline Av. weekly concentrate intake (g) & $585.33 \pm 14.84^{\mathrm{a}}$ & $399.00 \pm 11.15^{\mathrm{b}}$ & $265.00 \pm 11.15^{c}$ & * \\
\hline Av. daily concentrate intake(g) & $83.66 \pm 4.67^{\mathrm{a}}$ & $57.00 \pm 4.01^{\mathrm{b}}$ & $38.00 \pm 6.05^{c}$ & * \\
\hline Feed conversion efficiency (FCE) & $3.50 \pm 0.05^{\mathrm{a}}$ & $2.54 \pm 0.01^{\mathrm{b}}$ & $2.63 \pm 0.05^{\mathrm{b}}$ & * \\
\hline Av. daily Napier grass intake (g) & - & $19.12 \pm 2.03$ & $35.67 \pm .2 .33$ & * \\
\hline Survivability (\%) & $93.43 \pm 7.49^{\mathrm{a}}$ & $100 \pm 5.54^{\mathrm{b}}$ & $100 \pm 4.41^{\mathrm{b}}$ & * \\
\hline \multicolumn{5}{|c|}{$\begin{array}{l}\text { Values are expressed as Mean } \pm \mathrm{SEM} ; \text {; } \mathrm{a}, \mathrm{c} \text { Means within a row without common superscripts differ significantly; NS-non significant } \\
\text { statistically significant difference is expressed as }{ }^{\star}(\mathrm{P}<0.05) \text {. Here, } \mathrm{T}_{1}=100 \% \text { con., } \mathrm{T}_{2}=75 \% \text { con. }+25 \% \text { grass (DM basis) anc } \\
\mathrm{T}_{3}=50 \% \text { con. }+50 \% \text { grass (DM basis). }\end{array}$} \\
\hline
\end{tabular}

Table 3. Feed intake and growth performance of turkey fed on different level of Napier grass replacing concentrate

experimental period except for the week $11^{\text {th }}$ and $12^{\text {th }}$ (Figure 3). Body weight of $\mathrm{T}_{1}$ showed declined pattern for these two weeks. Concentrate intake was lower from 11 to $12^{\text {th }}$ week in $\mathrm{T}_{1}$ might be because of high environmental temperature (average $38^{\circ} \mathrm{C}$ ) occurred during this period. But concentrate in take, for the same period was higher in $\mathrm{T}_{2}$ and $\mathrm{T}_{3}$ might be due to supply of fresh grass which minimized the problem of high temperature. After $12^{\text {th }}$ week of age weight gain of $\mathrm{T}_{3}$ group showed decline trend might be due to lower consumption of concentrate and higher supply of grass; which resulted in lower nutrient intake for the growing turkey.

Daily concentrate intake was significantly lower in $\mathrm{T}_{2}$ than $\mathrm{T}_{1}$ but daily body weight gain was statistically similar between $\mathrm{T}_{1}$ and $\mathrm{T}_{2}$. Equivalent final body weight in $\mathrm{T}_{1}$ and $\mathrm{T}_{2}$ indicates that replacement of $25 \%$ concentrate by Napier grass had no detrimental effects on body weight gain. Rather there was a positive correlation between concentrate and grass intake. This result could be supported by who reported that turkey can obtain nutrients from forage because this poultry species is better able to digest fiber due to larger microbial population in their digestive tracts. Because of inclusion of forage, 'grass factor' worked for growth ${ }^{22}$. Similarly, highly significant differences in weight gain adding different types of fodder to poultry diets were found ${ }^{23}$. A laying hen could consume up to $120 \mathrm{~g}$ forage in a day and intake of forage decreased concentrate consumption without altering 
egg production ${ }^{24}$. Reducing of $15 \%$ concentrate had no detrimental effect on productivity of layers ${ }^{25}$. However, intake of forage materials depends on the type of forage materials. Poultry on pasture can consume 5 to $20 \%$ forage, depending on the age and quality of forage. However, although turkey can digest large quantity of fiber due to larger microbial population in their digestive tracts, this study showed that $50 \%$ concentrate replacement by grass was not suitable for the growing turkeys.

$$
=\mathrm{n}=\mathrm{T} 1 \quad==\mathrm{T} 2 \quad=x=\mathrm{T} 3
$$

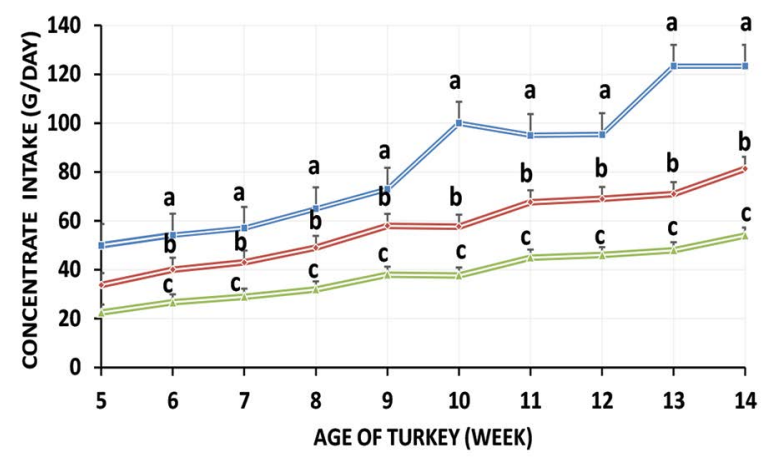

Figure 1. Weekly concentrate intake pattern of turkey. Each line with error bar represents the Mean \pm SEM values; different letters above the error bars of the same feeding period indicate statistically significant differences $(\mathrm{P}<0.05)$. Here, $\mathrm{T} 1=100 \%$ con., $\mathrm{T} 2=75 \%$ con. $+25 \%$ grass (DM basis) and $\mathrm{T} 3=50 \%$ con. $+50 \%$ grass $(\mathrm{DM})$.

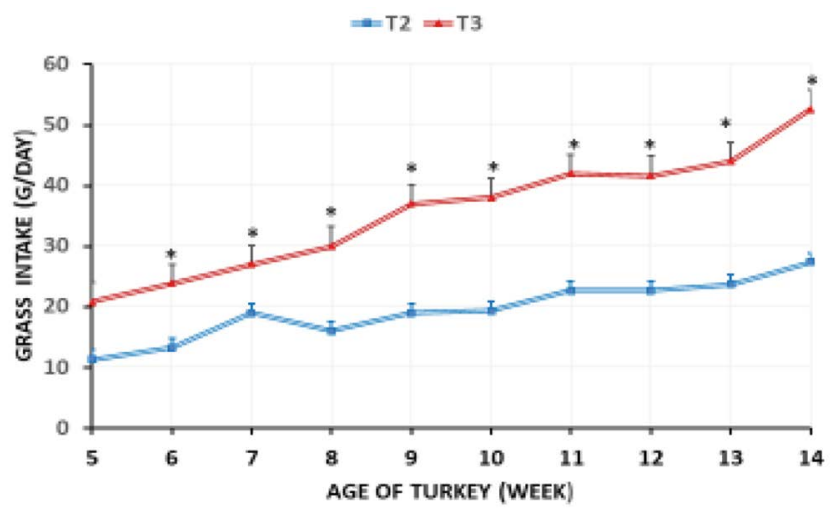

Figure 2. Weekly Napier grass intake pattern of turkey. Each line with error bar represents the Mean \pm SEM values; statistically significant difference is expressed as * $(\mathrm{P}<0.05)$ between the groups.Here, $\mathrm{T} 2=75 \%$ con. $+25 \%$ grass $(\mathrm{DM}$ basis) and $\mathrm{T} 3=50 \%$ con. $+50 \%$ grass (DM basis)

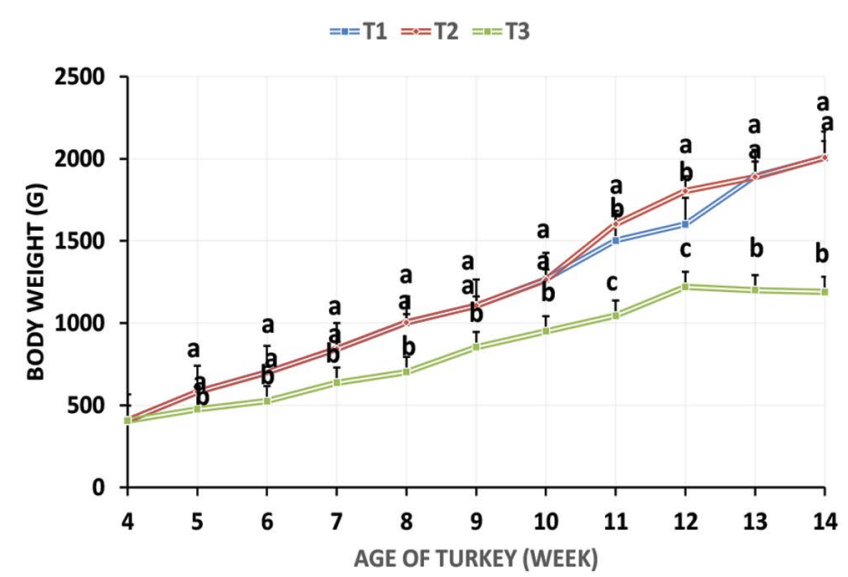

Figure 3. Average body weight of turkey in different weeks. Each line with error bar represents the Mean \pm SEM values; different letters above the error bars of the same feeding period indicate statistically significant difference $(\mathrm{P}<0.05)$. Here, $\mathrm{T} 1=100 \%$ con., $\mathrm{T} 2=75 \%$ con. $+25 \%$ grass (DM basis) and $\mathrm{T} 3=50 \%$ con.$+50 \%$ grass (DM basis)

\subsection{Feed Conversion Efficiency}

FCE was similar for $T_{2}$ and $T_{3}$, but these were significantly $(\mathrm{P}<0.05)$ lower than $\mathrm{T}_{1}$. Significantly higher FCE value for $T_{1}$ indicated poorer feed efficiency than $T_{2}$ and $T_{3}$. Statistically similar but lower FCE value for $\mathrm{T}_{2}$ and $\mathrm{T}_{3}$ indicated comparatively better feed efficiency. As the $\mathrm{T}_{1}$ group consumed only concentrate, so FCE value was higher. This result reflects that replacement of certain amount of concentrate by palatable grass give better feed efficiency with higher body weight, which happened in $\mathrm{T}_{2}$. This might be occurred because moderate levels of fiber acted as nutrient diluents and had not affect digestion and absorption of nutrients ${ }^{26}$. In fact, moderate amount of fiber increased space in gizzard which facilitated the function of HCL, bile acids and enzyme secretions. Feed efficiency of $\mathrm{T}_{3}$ was better because of lower amount of supplied concentrate intake as per treatment, but final body weight was the lowest. This might have happened due to higher intake of grass which contained fiber and thereby decreased weight gain. This result was consistent with the findings of who reported that higher fiber concentration in diet can cause negative effects on nutrient digestion and absorption. 


\subsection{Survivability}

Survivability rate differed significantly $(\mathrm{P}<0.05)$ among the experimental turkeys. Leg lameness and lesion on mouth was observed in turkeys of $\mathrm{T}_{1}$ group at the age of $9^{\text {th }}$ week and mortality occurred at $10^{\text {th }}$ week due to severe weakness. On the other hand no mortality occurred in $\mathrm{T}_{2}$ and $\mathrm{T}_{3}$ groups during the experimental period. There might be several positive reasons for $100 \%$ survivability in addition to proper intensive management. Fresh grass could supply vitamin-mineral and might be a source of unidentified factors which gave good vigor and livability to the turkey. This result could be supported by the findings of $\frac{24}{4}$ who observed in an indoor experiment 1.5 and $0.5 \%$ mortality in hens supplemented with maize silage and carrot, respectively, while15\% mortality was occurred in non-supplemented hens. Besides, an improved immune response in laying hens with access to forage materials has been reported by ${ }^{27}$, which might be one of the reasons for no mortality in the Napier grass supplied groups of the present study. In addition, forage materials have welfare benefits in terms of reduced feather pecking and other undesirable behavior ${ }^{28}$.

\subsection{Profitability}

The cost and return items associated with turkey production in the study are presented in Table 4. Variable costs for labor, medication, water, electricity, litter and transportation were non-significant. But variable costs for concentrate and Napier grass differed significantly $(\mathrm{P}<0.05)$. Though TFC did not differ significantly, TVC and TC differed significantly $(\mathrm{P}<0.05)$. On the basis of market price total revenue was similar for $\mathrm{T}_{1}$ and $\mathrm{T}_{2}$ but it differed significantly $(\mathrm{P}<0.05)$ from $\mathrm{T}_{3}$. Profitability variables NFI, PI, RRI and CTO also differed significantly $(\mathrm{P}<0.05)$ among the groups and these variables were highest for $\mathrm{T}_{2}$.

In case of profitability analysis it was observed that concentrate cost was significantly $(\mathrm{P}<0.05)$ lower for $\mathrm{T}_{2}$ and $T_{3}$ compared to $T_{1}$ because of using Napier grass. This result was in line with the findings of $\mathrm{f}^{29}$ who reported that Napier grass contain comparatively higher crude protein which served as a means of reducing feed cost. Intake of forage materials could reduce the concentrate consumption up to $20 \%$. Reduction of $12 \%$ concentrate intake was possible without altering egg production when birds were fed $108 \mathrm{~g}$ carrot per bird/day ${ }^{24}$. Inclusion of fresh forage to replace commercial concentrate for turkeys, help save money and could reduce production $\operatorname{costs}^{30}$.

TVC varied significantly because of variable amount of concentrate and grass intake. Concentrate feed cost was lowest and grass cost was highest in $\mathrm{T}_{3}$ group because this group consumed the lowest and highest amount of concentrate and grass, respectively. Similarly, TC differed significantly because of amount of concentrate and grass intake. But TFC remained same for all groups due to providing same facilities to all groups. Production cost per turkey was significantly lower in $\mathrm{T}_{2}$ and $\mathrm{T}_{3}$ due to replacement of concentrate by grass. But revenue per turkey was significantly lowest in $\mathrm{T}_{3}$ group due to lowest weight gain. On the other hand significantly higher total revenue was generated from both $\mathrm{T}_{1}$ and $\mathrm{T}_{2}$ group due to higher body weight gain. NFI was highest for $\mathrm{T}_{2}$ due to low feeding cost because of replacing concentrate by grass and gaining of higher body weight. Profitability parameters PI, RRI and CTO were significantly higher for $\mathrm{T}_{2}$ because this group incurred low cost but gained body weight equal to $\mathrm{T}_{1}$. From business point of view PI, RRI and CTO indicated that turkey farming following $\mathrm{T}_{2}$ model of feeding system i.e. replacing concentrate by $25 \%$ Napier grass; gave best results. PI 0.43 for $\mathrm{T}_{2}$ indicated that each $\mathrm{BDT}$ earned as revenue BDT 0.43, which returned to producer as net farm income. RRI 76.80\% indicated each taka invested in turkey business generated $76.80 \%$ net farm income. CTO 1.77 implied that for each BDT invested in the turkey business returned to turkey producers as revenue BDT 1.77.On the other hand replacement of $50 \%$ concentrate by grass resulted in the lowest RRI, PI and CTO; which indicated no loss-no profit situation in this study. But following this feeding system in the long run would cause loss for the farming enterprise. This result was consistent with the findings of ${ }^{31}-$ who reported capital turnover of 1.54 by turkey producers in Zaria, Nigeria. Moreover, it was reported that higher RRI means better success of farm business and a capital turnover ratio greater than 1 is acceptable for a farm business. It implies that to maximize profit from turkey farming, there should to be a well-planned effort towards increasing the scale of production and efficient use of the inputs. This study showed that efficient use of expensive concentrate through proper rationing with Napier grass can result in lowering feeding cost, increasing income and profit from turkey farming. This result is in agreement with the findings of who reported that feeding cost of turkeys was reduced by using fresh forage in Oaxaca of Mexico. 
Table 4. Cost and returns for per turkey production (calculation was made in BDT and on the basis of market price during the experimental period, in FY 2016-17)

\begin{tabular}{|c|c|c|c|c|}
\hline \multirow{2}{*}{ Parameter } & \multicolumn{3}{|c|}{ Dietary Treatment Groups } & \multirow{2}{*}{ Level of significance } \\
\hline & $\mathrm{T}_{1}$ & $\mathrm{~T}_{2}$ & $\mathrm{~T}_{3}$ & \\
\hline \multicolumn{5}{|l|}{ A. Variable cost } \\
\hline Labor & 95.5 & 95.5 & 95.5 & NS \\
\hline Concentrate & $246 \pm 13.55^{\mathrm{a}}$ & $168 \pm 12.67^{b}$ & $111 \pm 12.57^{c}$ & * \\
\hline Napier grass & - & $4.20 \pm 0.05^{\mathrm{a}}$ & $7.50 \pm 0.05^{\mathrm{b}}$ & * \\
\hline Medication & 12.67 & 12.67 & 12.67 & NS \\
\hline Water & 20.23 & 20.23 & 20.23 & NS \\
\hline Electricity & 33.33 & 33.33 & 33.33 & NS \\
\hline Transportation & 80 & 80 & 80 & NS \\
\hline Total Variable Cost (TVC) & $487 \pm 15.57^{\mathrm{a}}$ & $414 \pm 15.55^{\mathrm{b}}$ & $361 \pm 14.67^{\mathrm{c}}$ & $*$ \\
\hline \multicolumn{5}{|l|}{ B. Fixed costs } \\
\hline Cost of poult & 700 & 700 & 700 & NS \\
\hline Depreciation on housing @5\% & 24.33 & 24.33 & 24.33 & NS \\
\hline Depreciation on equipment@10\% & 1.67 & 1.67 & 1.67 & NS \\
\hline Total Fixed Cost (TFC) & 726 & 726 & 726 & NS \\
\hline Total cost & $1213 \pm 109.4^{\mathrm{a}}$ & $1140 \pm 106.8^{\mathrm{b}}$ & $1087 \pm 107.7^{c}$ & * \\
\hline \multicolumn{5}{|l|}{ C. Revenue } \\
\hline Sales of Turkeys & $2006 \pm 109.7^{\mathrm{a}}$ & $2008 \pm 108.7^{\mathrm{a}}$ & $1190 \pm 107.6^{c}$ & * \\
\hline Sales of litter & $6.67 \pm 0.33$ & $6.67 \pm 0.54$ & $6.67 \pm 0.57$ & NS \\
\hline Total Revenue (TR) & $2013 \pm 107.7^{\mathrm{a}}$ & $2015 \pm 108.8^{\mathrm{a}}$ & $1197 \pm 107.5^{\mathrm{b}}$ & * \\
\hline Net farm income (NFI) & $799 \pm 12.35^{\mathrm{a}}$ & $875 \pm 13.24^{\mathrm{b}}$ & $110 \pm 12.37^{c}$ & * \\
\hline Profitability index (PI) & $0.40 \pm 0.01^{\mathrm{b}}$ & $0.43 \pm 0.01^{\mathrm{a}}$ & $0.09 \pm 0.00^{c}$ & * \\
\hline Rate of return on investment (RRI) & $65.87 \pm 2.22^{\mathrm{b}}$ & $76.80 \pm 2.55^{\mathrm{a}}$ & $10.14 \pm 0.57^{\mathrm{c}}$ & * \\
\hline Capital turnover(CTO) & $1.66 \pm 0.01^{b}$ & $1.77 \pm 0.02^{\mathrm{a}}$ & $1.10 \pm 0.01^{\mathrm{c}}$ & * \\
\hline
\end{tabular}

\section{Conclusion}

Finally, it was concluded that on the basis of DM, replacement of $25 \%$ concentrate by Napier grass resulted in not only equal weight gain as like $100 \%$ concentrate but also reduced cost of production without causing any detrimental effects on turkey aged between 5 to 14 weeks. Therefore, replacement of $25 \%$ concentrate by Napier grass could be recommended for the turkey farmers of Bangladesh. But further study is needed to reinforce the findings.

\section{Acknowledgements}

The authors gratefully acknowledge the support of the sub-project 'Enrichment of Research Capabilities for Postgraduate Studies on Advanced Animal Science' CP \# 3314, Window-2, HEQEP/UGC/World Bank to accomplish the study successfully. 


\section{References}

1. Roberson KD, Rahn AP, Balander RJ, Orth MW, Smith DM, Booren BL, Booren AM, Osburn WN, Fulton RM. Evaluation of the growth potential, carcass components and meat quality characteristics of three commercial strains of tom turkeys. Journal of Applied Poultry Research. 2003; 12:229-36. https://doi.org/10.1093/japr/12.2.229

2. Nestor KE, Anderson JW, Hartzler D, Velleman SG. Genetic variation in pure lines and crosses of large-bodied turkeys. 4. Body shape and carcass traits. Poultry Science. 2005; 84:1825-34. PMid16479937. https://doi.org/10.1093/ ps/84.12.1825

3. East African's grasses and fodder: Their ecology and husbandry. 1993. https://www.springer.com/in/ book/9780792318675

4. Selection for improved efficiency in poultry, progress to date challenges for the future. 2014. http://www.wcgalp. org/proceedings/2014/selection-improved-efficiencypoultry-progress-date-and-challenges-future

5. Technology transfer, policies and the global livestock revolution. 2008. http://www.ifpri.org/publication/ technology-transfer-policies-and-role-private-sectorglobal-poultry-revolution

6. Soliven ME. Rural turkey rearing in the Philippines. Poultry International. 1984; 6:94-5.

7. Pasture-raised poultry nutrition. 2002. file://C:/Users/a/ Downloads/chnutritionhpinew.pdf

8. Nutrition and feeding of organic poultry.2008.https://books. google.co.in/books/about/Nutrition_and_Feeding_of_ Organic_Poultry.html?id=9WZ9LJLoCZIC\&redir_esc=y

9. Angkanaporn K, Choct M, Bryden WL, Annison EF, Annison G. Effects of wheat pentosans on endogenous amino acid losses in chickens. Journal of Science of Food and Agriculture. 1994; 66:399-404. https://doi.org/10.1002/ jsfa.2740660319

10. Chen YH, JC Hsu JC, YU B. Effects of dietary fiber levels on growth performance, intestinal fermentation and cellulase activity of goslings. Journal of Chinese Society of Animal Science. 1992; 21:15-28.

11. Nutrient requirements of poultry. 1994. https://www. nap.edu/catalog/2114/nutrient-requirements-of-poultryninth-revised-edition-1994

12. Gonzalez-Alvarado JM, Jimenez-Moreno E, Valencia DG, Lazaro L, Mateos GG. Effects of fiber source and heat processing of the cereal on the development and $\mathrm{pH}$ of the gastrointestinal tract of broilers fed diets based on corn or rice. Poultry Science. 2007; 87:1779-95. PMid: 18753446. https://doi.org/10.3382/ps.2008-00070

13. Hetland H, Svihus JB, Choct M. Role of insoluble fiber on gizzard activity in layers. Journal of Applied Poultry
Research. 2005; 14:38-46. https://doi.org/10.1093/ japr/14.1.38

14. Hetland H, Svihus B. Inclusion of dust bathing materials affects nutrient digestion and gut physiology of layers. Journal of Applied Poultry Research. 2007; 16:22-6. https:// doi.org/10.1093/japr/16.1.22

15. Shivus B. The gizzard: Function, influence of diet structure and effects on nutrient availability. World's Poultry Science Journal. 2011; 67:207-24. https://doi.org/10.1017/ S0043933911000249

16. Hetland H, Svihus B, Olaisen V. Effect of feeding whole cereals on performance, starch digestibility and duodenal particle size distribution in broiler chickens. British Poultry Science. 2003; 43:416-23. PMid: 12195801. https://doi. org/10.1080/00071660120103693

17. Nurmi E, Ratala M. New aspects of Salmonella infection in broiler production. Nature. 1973; 241:210-1. PMid: 4700893. https://doi.org/10.1038/241210a0

18. Esmail S. Fibre plays a supporting role in poultry nutrition. World Poultry Magazine. 2012 Feb. 2017. http://www. worldpoultry.net/Breeders/Nutrition

19. Unconventional food for monogastricos. Experiences in the Mexican tropics. 2014. https://translate.google. com/translate?hl=en\&sl=es\&u=https://www.academia. edu/ $19051398 /$ ALIMENTACI\%25C3\%2593N_

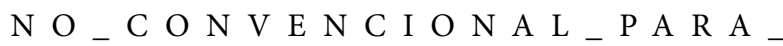
MONOG\%25C3\%2581STRICOS._EXPERIENCIAS_EN_ EL_TR\%25C3\%2593PICO_MEXICANO\&prev=search

20. Aganga AA, Omphile UJ, Thema T, Baitshotlhi JC. Chemical composition of Napier grass (Pennisetum purpureum) at different stages of growth and Napier grass silages with additives. Journal of Biological Sciences. 2005; 4:493-6. https://doi.org/10.3923/jbs.2005.493.496

21. SPSS. 2013. https://spss-64bits.en.softonic.com/

22. Blair R. Nutrition and feeding of organic poultry. British Poultry Science. 2010; 51(2):309. https://doi. org/10.1080/00071660902763965

23. Hong S. Duckweed versus ground soja beans as supplement for scavenging native chickens in an integrated farming system. Livestock Research for Rural Development. 1999; 11(1):10-1.

24. Steenfelds S, Kjaer JB, Engberg RM. Effect of feeding silages or carrots as supplements to laying hens on production performance, nutrient digestibility, gut structure, gut microflora and feather pecking behavior. British Poultry Science. 2007; 48:454-68. PMid: 17701499. https://doi.org/10.1080/00071660701473857

25. Management of laying hens in mobile houses - a review of experiences. 1999. https://www.cabdirect.org/cabdirect/ abstract/20013092888 
26. Hetland H, Svihus B. Effect of oat hulls on performance, gut capacity and feed passage time in broiler chickens. British Poultry Science. 2001; 42:354-61. PMid: 11469556. https:// doi.org/10.1080/00071660120055331

27. El Lethey H, Aerniv V, Jungi TW, Wechsler B. Stress and feather pecking in laying hens in relation to housing conditions. British Poultry Science. 2000; 42:22-8. PMid: 10821518. https://doi.org/10.1080/00071660086358

28. Van Krimpen MM, Kwakkel RP, Reuvekamp BFJ, Van der Peetschwering CMC, Den Hartog LA, Verstegen MWA. Impact of feeding management on feather pecking in laying hens. World Poultry Science Journal. 2005; 61:663-85. https://doi.org/10.1079/WPS200478
29. Almeida GFD, Hinrichsen LK, Horsted K, Thamsborg SM, Hermansen JE. Feed intake and activity level of two broiler genotypes foraging different types of vegetation in the finishing period. Poultry Science. 2012; 91:2105-13. PMid: 22912443. https://doi.org/10.3382/ps.2012-02187

30. Use of the leaf of Chaya (Cnidoscolus chayamansa) and of Huaxín (Leucaena leucocephala) in the feeding of Creole birds. 2011. https://translate.google.com/ translate?hl=en\&sl=es\&u=https://www.medigraphic.com/ cgi-bin/new/resumen.cgi\%3FIDARTICULO\%3D22097\&p rev=search

31. Ajala MK, Nwagu BI, Sekoni AA, Adeshinwa AOK. The profitability of turkey production in Zaria, Kaduna state, Nigeria. Asian Journal of Information Technology. 2007; 1:27-33. 